Economics Development Analysis Journal 6(4)(2017) Economics Development Analysis Journal

\title{
The Strenghtening Strategy of Tax Parking in Semarang Regency
}

\author{
Rizki Novela Hanydar ${ }^{1 凶}$, Yozi Aulia Rahman ${ }^{2}$
}

Economics Development Department, Economics Faculty, Universitas Negeri Semarang

\section{Article Info}

Article History:

Received July 2017

Accepted September 2017

Published November

2017

Keywords:

Strategy, Reinforcement,

Parking Tax Revenue,

Analytic Hierarchy

Process, Semarang

Regency

\begin{abstract}
The purpose of this research is to know and analyze the acceptance of parking tax, obstacles faced, and exact strategy which is used to strengthening of parking tax revenue of Semarang Regency. Parking tax revenue in Semarang Regency has enormous potential. Increase in every year does not necessarily make the parking tax revenue to contribute greatly to the tax revenue area of Semarang regency. Parking tax revenues even in 2013 are only $7 \%$ of local taxes. The effectiveness also has a trend that tends to decline every year. The method used in this research is quantitative research method using four analysis that is growth analysis, contribution analysis, effectiveness analysis, and analysis of AHP (Analytic Hierarchy Process). Informants from this research consists of 8 keypersons consisting of elements of government service and taxpayer parking. AHP is used to process the data and select the most important and appropriate aspects and alternatives to which not to strengthen the parking tax revenue of Semarang Regency. The result of research by using Analitycal Hierarchy Process (AHP) can be seen that the strategy of strengthening of parking tax revenue of Semarang Regency 2010-2016 consists of several criteria of program prioritized in the process of strengthening the first criteria of taxpayer participation (weight value 0.425), the two regulatory criteria Weighted value 0.242), third, socialization criteria and excellent tax service (weight value 0.198), and four criteria of implementation of the regulation (weight value 0.135). Alternative priority program is to increase the participation of taxpayers (weight value 0.288). Furthermore, the policy of setting the target of parking tax (weight value 0.164 ) and increase taxpayer compliance (weighted value $0.144)$.
\end{abstract}

\footnotetext{
$凶$ Corresponding Author:

Building L2, $2^{\text {nd }}$ Floor, Sekaran Campus,

Gunungpati, Semarang

E-mail: edaj@mail.unnes.ac.id
} 


\section{INTRODUCTION}

Development at the national and local levels is currently done to improve the welfare and prosperity of the community. In accordance with the ideals of the Indonesian people as stipulated in the 1945 Constitution which reads "to promote the general welfare", so that existing development in the region is part of national development. While the development of the region itself is strived for the area can manage the potential of the region with the community and improve the development of the economy and create a new job for the community.

The main objective of regional autonomy is to improve public services and promote the regional economy. Basically it contains three main missions in connection with the implementation of Regional Autonomy and Decentralization that is creating the efficiency and effectiveness of the management of local resources, improving the quality of public services and community welfare, and empowering and creating space for the community to participate (participate) in the development process (Mardiasmo, 2002: 99). Then, local governments can explore and utilize the potential in their respective areas in order to achieve its accelerated development in each region regardless of the central government. Because the local government and surrounding communities who know the conditions in their respective regions. For that it needs a good cooperation between local government and local communities to build the area.

In the era of regional autonomy, local governments are given the flexibility to manage and explore their potential for welfare of the community and the improvement of regional development. One of them is managing each of his own regional acceptance. Based on Law No. 33/2004 on Fiscal Balance between Central and Regional Governments, local revenue sources comprise of Local Revenue (PAD), Balancing Funds, Regional Loans, and Other Legitimate Receipts.

The management of local revenue sources is very important for the development of infrastructure in the region and the improvement of the community's welfare, in order to realize the equitable distribution of development in the region. The increasing number of development each year and coupled with the rising population and the necessities of life is a problem and the burden of development that should be observed, the problem-solving efforts and the burden of development demand the role of government on an ongoing basis. The increasing role of the government in solving the problem has resulted in increased funding needed to finance government spending on development and community (Pattiasina, 2011: 35).

One of the region's main revenue is the local taxes. At the local tax collection, the local government of Semarang regency gives authority to DPPAD (Regional Revenue and Asset Management) which in 2017 changed its name to BKUD (Regional Finance Agency) which has the authority to manage and increase the revenue on local taxes and find each the potential that can be developed from each type of revenue contained in the local tax. Taxation is a very important means by which governments raise revenue for financing their projects. Such projects include: construction of roads, provision of health care, provision of qualitative education, provision of water, provision of electricity which are common features of modern society today (Nwamuo, 2017). Umar (2017) said taxation is fiscal social contract implies that citizens should pay tax which is utilized by government to execute programs for the collective good.

Local taxes that are managed by BKUD of Semarang Regency are 11 types, namely: Hotel Tax, Restaurant Tax, Entertainment Tax, Advertising Tax, Street Lighting Tax, NonMetallic and Mineral Tax, Parking Tax, Ground Water Tax, Land Acquisition Duty and / or Building, Swallow's Nest Tax, and Land and Building Rural and Urban Taxes. This is in accordance with the provisions in the Regional Regulation of Regency of Semarang No. 4 of 2012 on Amendment to Regional Regulation of Regency of Semarang Number 10 of 2010 on Regional Tax contained in Article 3 which describes the Type of Local Tax. 
The revenue of PAD Semarang Regency always increases annualy. The largest revenue comes from Other Legitimate PAD which is Rp 489.310.871.000.000, -. Among these four sources, local taxes and regional levies are the mainstay source of local revenue in Semarang regency. The realization of local taxes from year on year always increases. The largest realization occurred in 2015, namely $\mathrm{Rp}$ $95,576,297,000,000,-$ and the lowest occurred in 2010 that is Rp 26.228.584.000.000,-. Both are potential sources of revenue that can be developed to accelerate development in the region.

Realization of parking tax revenue Semarang always increase every year. Then, the parking tax revenue in Semarang regency that reaches the set target only in 2011, 2012, and

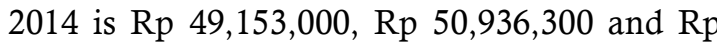
107,923,929 respectively. In 2010, 2013, 2015 and 2016, parking tax revenue was below the target, even in 2013 the realization of the parking tax was only Rp. 56,488,350 only accounted for $18 \%$ of the target set. Although the realization of the parking tax always increased, but only in a few years the acquisition of parking tax realization reached the target. It is far away from the desired expectations by local governments that certainly set targets in accordance with the potential that can be utilized by the parking tax revenue in Semarang regency.

\section{RESEARCH METHOD}

The type of this research is quantitative research. This study uses a numerical data. The data used in this research are primary and secondary data types. While the primary data for the formulation of the policy in the Hierarchy Analysis Process (AHP) obtained from keypersons, including the determination of criteria in order to achieve the purpose of strengthening the parking tax revenue of Semarang regency. Determination in the selection of alternative programs that can be taken to increase the parking tax revenue of Semarang regency. Secondary data is data obtained from related institutions such Central
Statistics Bureau (BPS), Regional Finance Agency, and others.

This study uses four analytical methods namely growth analysis, contribution analysis, effectiveness analysis, and Analysis Hierarchy Process (AHP). The four methods of analysis are expected to answer all existing problems. AHP method is used for the purpose of knowing which programs need to be prioritized in the strategy of strengthening of parking tax revenue in Semarang regency. Therefore, this research requires some parties deemed competent (keypersons) representing to determine alternative programs in an effort to strengthen the parking tax revenue of Semarang regency.

\section{RESULTS AND DISCUSSION}

The percentage of growth in the realization of parking tax revenue in Semarang Regency is volatile, even the percentage of growth tends to be slow. Local government set a target in accordance with the potential that exist. However, the realization usually less than the target. In 2013-2014, parking tax revenue growth 1.91 percent. This could happen because BKUD increase supervision intensity, so parking tax revenue can be improved. While in 2015-2016 the percentage of parking tax revenue growth is the lowest that is equal to 1 percent. There are factors that cause the growth of tax revenue parking is still lacking. One of them is the lack of awareness of the taxpayer to carry out these obligations. Supposedly, this is the concern of the local government of Semarang regency to be able to increase the parking tax revenue of Semarang regency in order to increase the growth of parking tax revenue of Semarang regency.

The realization of parking taxes in Semarang has increased annualy. The contribution of tax revenue to the tax on the district of Semarang is still very low. From 20102016 the contribution of parking tax revenue to local taxes is still lacking. Its contribution is still below than 20 percent, even revenue in 2013 contribute only 7 percent. In accordance with the criterion of contributions if 0.00 percent -100 percent is categorized very less. If it is seen to 
keep increasing the volume of vehicles in each year, it should be a huge potential for parking tax revenue but in fact the contribution of the parking tax revenue is still very less to the local taxes of Semarang regency.

Parking tax receipts from 2010-2016 have an unstable effectiveness. Only in 2011, 2012, and 2014 were the effectiveness rates above 100 percent, respectively 102 percent, 106 percent, and 113 percent, which means it was categorized as very effective. Even in 2013 the rate of parking tax revenue effectiveness is only 18 percent, which means not effective. It is happed due to the local government of Semarang regency set the target that was too high in 2013. At that time, there was a management transition that occurred in BKUD Semarang regency so that the targeting for the parking tax is not in accordance with the previous year.

Based on the keypersons opinion. It shows that the criteria of taxpayer participation (weight value 0.425 ) is the most important criteria that need to be considered in the strengthening of parking tax revenue in Semarang regency 20102016. The next criteria are regulatory criteria $(0.242)$, socialization criteria and excellent tax service (0.198), and regulatory implementation criteria (0.135).

AHP analysis use to determine the priority aspect who provided information on what aspects should be improved or implemented in order to strengthen the parking tax revenue in Semarang regency. The results of this analysis obtained from keypersons who became respondents. The aspects that become criteria from the most priority to the least priority will be broken down into alternatives from each of these priorities.

The most important aspect that becomes a priority in strengthening the tax revenue of Semarang Regency is the aspect of taxpayer participation. In the aspect of taxpayer participation itself there are three alternatives that serve as a reference in an effort to strengthen the tax revenue of parking is to increase the participation of taxpayers and improve taxpayer compliance.
Based on the results of AHP analysis it is known increase taxpayer participation is the most priority alternative in the strengthening of parking tax revenue from the aspect of taxpayer participation with priority percentage of 66.7 percent. Furthermore, the second priority in order to strengthen the parking tax revenue from the aspect of taxpayer participation is to increase taxpayer compliance with priority percentage of 33.3 percent. From this result, we obtained an alternative strategies that need to be done to strengthen the tax revenue parking in Semarang regency from the aspect of taxpayer participation.

The next aspect of the second priority in the strategy of strengthening the tax revenue is the regulatory aspect. The regulation aspect earns a priority percentage of 24.2 percent or becomes the second largest after the taxpayer participation aspect. In the regulation aspect, there are two alternative strategies, namely the policy of targeting of parking tax and parking tax collection mechanism. The policy of targeting the parking tax is a top priority in the regulatory aspect, with a percentage of 77.8 percent. The policy of targeting the parking tax becomes the main priority because it has not been effective. The second priority is the mechanism of parking tax collection with a percentage of 22.2 percent.

In the aspect of socialization and service, there are two alternatives that are used to strengthen the parking tax revenue in Semarang regency which is periodic socialization and improve service and guidance.

The main priority alternative in the strengthening of parking tax revenue from the aspect of socialization and excellent tax service is socialization periodically with the priority percentage of 79.2 percent. Then the second priority is to improve service, direction, and coaching with a priority percentage of 20.8 percent.

In this study it is known that the fourth priority in the strengthening of parking tax revenue is the implementation of regulation. In the implementation of regulation aspect, there are four alternatives that become the reference, among others, to make forced sanctions, increase supervision on a regular basis, the 
implementation of licensing rules, and the implementation of fit test on a regular basis. The main priority in the strengthening of parking tax revenue from the aspect of implementing the regulation is to make a forced sanction with priority percentage of 48.8 percent. Furthermore, the second priority is the implementation of the fit test on a regular basis with the priority percentage of 20.7 percent. Subsequently, the third and fourth priorities are to increase regular monitoring and implementation of licensing rules that share a priority percentage of 15.2 percent.

The result of the overall analysis shows that the policy of increasing taxpayer participation is the main priority alternative when compared with other alternatives. The alternative sequence of the strengthening strategy of parking tax revenue in Semarang Regency is the most priority to increase the participation of taxpayers. Taxpayers participation with the percentage of 28.8 percent become the main priority. Then the second priority is the targeting the parking tax from the aspect of regulation with the percentage of 16.4 percent, the third priority is to improve taxpayer compliance from the aspect of taxpayer participation with the priority percentage of 14.4 percent.

Furthermore, the fourth priority is the socialization periodically from the aspect of socialization and excellent tax service with priority percentage of 13.4 percent. Percentage of priority of 9.1 percent priority alternatives impose penalties from the aspect of implementing the regulation to the fifth priority alternative.

The sixth Priority is parking tax collection mechanism from the aspect of regulation with priority percentage of 4.7 percent. Then, the implementation of periodic test of the aspects of the implementation of the regulation becomes the seventh priority with a percentage of 3.9 percent.

The eighth priority is to improve services and guidance from the aspect of socialization and excellent tax service with a percentage of 3.5 percent. Successively the ninth and tenth priorities are the implementation of licensing regulations from the aspect of implementing the regulation and increasing the regular supervision of the implementation aspect of the regulation, which has a percentage of 2.9 percent.

\section{CONCLUSION}

Based on the results of research and discussion, it can be concluded that the revenue of parking tax in Semarang regency in 2010-2016 has a realization that tend to increase every year. Consecutive parking tax receipts from 2010-2016 are as follows: $\mathrm{Rp} 28.141 .500, \mathrm{Rp} 49.153 .300, \mathrm{Rp}$ 50.936.300, Rp 56.488.350, Rp 107.923.929, Rp 139.117.093, Rp 139.725.895. The growth of realization of parking tax revenue from the year has a fluctuating trend. The largest realization growth occurred in the 2013-2014 interval of 1.91 percent. The contribution of taxable parking revenue of Semarang Regency to local taxes is still very low. Then, the effectiveness of parking tax in Semarang Regency is still not effective.

The obstacles faced by Semarang regency in terms of parking tax revenue are among others the awareness or participation level of the taxpayer is still lacking to carry out its obligations. The number of leaks in parking tax collections, there are persons who take advantage of this opportunity to gain personal benefits. Furthermore, the feasibility test has not been conducted periodically. This causes the low level of taxpayer compliance. The last obstacle is the lack of coaching intensity given to the parking manager. Therefore, there is a lack of understanding in the management and determination of the amount that must be paid by the taxpayer later.

Based on the results of AHP analysis, the election of taxpayer participation criteria (0.425) as the main priority reflects that the strengthening of parking tax revenue Semarang regency is closely related to the level of taxpayer participation and taxpayer compliance level. It is based on fact in the field of taxpayer participation rate has a percentage of only 30-40 percent, which is still very low if you want to optimize the parking tax revenue of Semarang regency. The next criterion that becomes second priority is the 
regulation with the weight value of 0.242 . Then the third priority is the socialization and excellent tax service with a weight value of 0.198 and the last criteria of the fourth priority is the implementation of the regulation with a weight value of 0.135

\section{REFERENCES}

Regional Finance Agency of Semarang Regency. 2010-2016. Local Tax of Semarang Regency Year 2010-2016. Regency of Semarang. BKUD.

Central Statistics Agency of Central Java Province. 2010-2015. Central Java in the figures 20112016. Semarang. BKUD

Central Statistics Agency of Semarang Regency. 20102016. Regency of Semarang in figures 20102016. Regency of Semarang. BKUD.

Gomes, Stevanus J. and Victor Pattiasina. 2011. Analysis of Local Tax Contribution and Regional Retribution to Local Own Revenue in Southeast Maluku Regency. Journal of Assets: Page 35 .

Mardiasmo. 2002. Public Sector Accounting. Yogyakarta: Andi.

Nwamuo, C. 2017. Multiple Taxation and the Operations of Business Enterprises in Aba Metropolis. Pyrex Journal of Business and Finance Management Research, 3(6), 132-138.

Peraturan Daerah Kabupaten Semarang Nomor 10 Tahun 2010 Tentang Pajak Daerah Dan Perubahannya.

Umar, M. A., Derashid, C. 2017. What Is Wrong With the Fiscal Social Contract of Taxation in Developing Countries? A Dialogue With SelfEmployed Business Owners in Nigeria. SAGE Journal, 7(4).

Undang-Undang No 33 Tahun 2004 Tentang Perimbangan Keuangan Antara Pemerintah Pusat dan Daerah. 